\title{
Attitude of Farmers towards the Agricultural Extension System of State Department of Agriculture
}

\author{
Manisha Pandey, Dhriti Solanki and Shalini Pandey* \\ Department of Extension Education and Communication Management, \\ College of Community and Applied Sciences,Maharana Pratap University of Agriculture \& \\ Technology, Udaipur, India \\ *Corresponding author
}

\begin{abstract}
A B S T R A C T
The objective of the present study was to ascertain the attitude of farmers towards the agricultural extension system of the State Department of Agriculture. The sample consisted of randomly selected 90 farmers from 09 villages of three subdistricts of Udaipur who were regularly in contact with the department functionaries for the last 3 years. For measurement of attitude, Thurston's equal appearing interval technique was used to construct the scale. Personal interview technique was used for collecting data from the respondents. Frequency distribution, percentage and mean weighted score were used for the analysis of data. The outcome of the study divulges that nearly half of the respondents $(47.78 \%)$ were having an unfavourable attitude towards the transfer of technology system of Department of Agriculture whereas, 32.22 per cent of the respondents were favourably disposed to the extension services of the State Department of Agriculture. There were only 20.00 per cent of the respondents who had a neutral attitude towards the services of the department. None of the respondents showed the most favourable and the most unfavourable attitude towards the extension system.
\end{abstract}

\section{Keywords}

Attitude, Farmers, extension system, Extension services, Public extension system

Article Info

Accepted:

04 March 2020

Available Online:

10 April 2020

\section{Introduction}

The term 'agricultural extension' is a professional communication intervention deployed by public and private agencies or organizations to disseminate agriculture knowledge and technologies to rural communities. The public sector agency represented by the State Department of
Agriculture is disseminating the agriculture and allied technologies among the farm families over the last few decades. The attitude is considered as the main variable or factor that has a great impact on the adoption rate of any technology by farmers and consequently, on the overall production rate. Experiences have shown that the favourable attitude towards any programme is bound to 
have an accumulative effect in the form of favourable reaction of the beneficiaries to make the programme successful. Hence, keeping this in mind, the present study was undertaken to study the attitude of the farmers towards the services of the State Department of Agriculture. There were a total of 25 statements for measuring the attitude of the farmers towards the services of the department. Of these, 13 were positive and 12 were negative statements which were weighted on a five-point continuum.

\section{Materials and Methods}

The study was conducted in the Udaipur district of Rajasthan state. The Udaipur district from the viewpoint of agriculture is divided into three sub-districts viz., Girwa, Badgaon and Salumber. All three sub-districts were included in the study. From each subdistrict, three villages which were within a radius of $50 \mathrm{~km}$ from the sub-district headquarter were selected on a random basis. Thus, a total of nine villages were taken from the three sub-districts to have a representative sample.

The total sample of the study consisted of 90 farmers who were regularly in contact with the State Department of Agriculture functionaries for the last 3 years. For measurement of attitude,

Thurston's equal appearing interval technique was used to construct the attitude scale. Total 25 statements were selected of which thirteen statements were the indicators of favourable attitude towards the extension system and the remaining twelve were indicating unfavourable attitude. The data collected from the respondents were scored, tabulated and analyzed by using suitable statistical tools such as frequency distribution, percentage and mean weighted score.

\section{Results and Discussion}

Background information of the
respondents

Half of the respondents $(50.00 \%)$ belonged to the age group of $46-60$ years followed by 41.11 per cent respondents who were in the age group of 31-45 years. Majority of the respondents were under reserve caste categories which included OBC (38.88\%) and SC/ST (37.77\%). Regarding education, more than one-fourth of the respondents $(25.55 \%)$ were illiterate followed by 22.22 per cent respondents who were educated up to middle level. Agriculture was the main occupation of all the respondents. However, the majority of them were also involved in some subsidiary occupation along with agriculture. Regarding family structure, more than half of the respondents $(57.77 \%)$ were from a joint family consisting of 5-8 members. More than 40 per cent respondents had a landholding of 2.6- 5.0 acres while 37.77 per cent had landholding less than 2.5 acres. About annual income, 37.77 per cent of respondents had an annual income between ' 1 to 1.5 lakhs followed by 35.55 per cent respondents who had annual income up to ` 1 lakh.

\section{Statement wise attitude of the farmers towards the agricultural extension system of the State Department of Agriculture}

Critical analysis of Table 1 highlights that greater percentage of the respondents (78.88\%) strongly agree or agree with the negative statement that there is difficulty in contacting field functionaries of the State Department of Agriculture with 2.02 MWS. The respondents reported that many a time they faced difficulty in getting technical guidance due to the unavailability of the concerned agriculture supervisor at Kisan Seva Kendra or field. When the reason was discussed with the functionaries, they stated 
that except on Thursday, they have to visit villages in the operational area. Hence, probably when the farmers visited the KSK, the concerned functionary might not be available at that time. Similarly, the equal number of respondents strongly agreed or agreed that proper guidance is not provided by SDoA personnel for initiating sound economic activity or establishment of agrobased enterprise with 1.68 MWS. The respondents expressed that the departmental activities mainly focus on crop production and little emphasis has been given on postharvest management including value addition and marketing of the produce. Some of the respondents reported that in the training programmes meant for farmers due consideration has not been given to the entrepreneurship development among them.

Furthermore, 76.66 per cent of the respondents with 2.17 MWS agreed with the statement that only resourceful farmers are benefitted by the department services. Majority of the respondents (74.43\%) strongly agree or agree with the negative statement that existing infrastructure and facilities of SDoA are not enough to meet the needs of the farmers (2.14 MWS). The respondents revealed that many a time the department is not able to supply the required inputs in time and sufficient quantity. Similar findings were reported by Tawari and Davies (2010) who revealed dissatisfaction of fisher folks towards agricultural extension services. According to findings more than half of the respondents $(58.2 \%)$ disagreed with respect to the adequacy of implements as provided by the extension agencies. The respondents also disagreed with the fact that the implements available were in usable condition and were in use.

There were 72.21 per cent of the respondents who strongly agree or agree with the statement that the farmers meetings are not regularly conducted by the agriculture supervisors due to which many a time they remain unaware about the services and programmes of the department in their areas such as organization of training, demonstrations, farm school, targets for subsidy, soil testing and distribution of agricultural inputs.

Nearly 70 per cent of the respondents disposed unfavourable attitude towards the activities of the SDoA and agree with the negative statement that the SDo Aactivities are confined only to a few crops and did not cover the allied fields such as animal husbandry, poultry, dairy etc (2.46 MWS). Likewise, 66.66 per cent of the respondents believed that the SDoA services fail to develop self-reliance among the farmers and farm women due to little emphasis on income-generating activities. Further, 65.55 per cent respondents strongly agree or agree with the negative statement thatthere is no adequate follow-up of the department programmes/activities due to which many a time the farmers did not get on the spot solution of their field problems. Similarly, 63.32 per cent respondents unfavourably disposed to the statement that the SDoA activities seem to be same from year to year (2.26 MWS). The farmers reported that over the years there is no change in the programmes of the department. This has sidetracked the real needs of the farming community.

Table 1 further reveals that more than 60 per cent of the respondents showed their disagreement towards the positive statement that extension functionaries of SDoA make use of farmer's suggestions in subsequent programmes/activities (2.48 MWS $)$. Similarly, 59.99 per cent of the respondents displayed their unfavourable attitude towards the KCC service and disagree with the statement that phone-in-line (KCC) with 
scientist gives first-hand information about queries. It was due to a lack of awareness among the farmers about KCC services.

It was found that the farmers have an unfavourable attitude towards most of the aspects of the extension system of the department. However, they exhibited a positive response in some of the statements. Data in the table reflect that majority of the respondents $(74.43 \%)$ found to strongly agree or agree with the positive statement that the department has well qualified and trained manpower (3.85 MWS). Most of the respondents accepted that the AAOs and ASs are technically sound to solve many of their field problems. Similarly, 70.00 per cent of the respondents strongly agreed or agreed with the statement that Kisan Seva Kendra helps to solve the urgent problems of farmers regarding input arrangement, insect and pest control etc. The findings of Jaisridhar et al. (2013) also revealed that nearly half of the dairy farmers $(46.67 \%)$ had favorable attitude towards KCC services. The respondents were satisfied with the demonstrations conducted by the department and accepted that the FLDs encourages them to adopt newly released crop production technology (3.68 MWS). There were 65.55 and 62.21 per cent respondents who agree that the department of agriculture timely organizes need-based training and the information disseminated through the department is of practical use to farmers, respectively. The respondents also had favourable opinion towards the statement that SDoA offers its services through multiple extension methods such as training, demonstrations, farm school and farm journalism (3.74 MWS). Moreover, nearly half of the respondents strongly believed that crop production has substantially increased due to the introduction of the SDoA services in the area and regular contacts of the farmers with the field functionaries of the department motivated them to adopt improved practices.

Table.1 Statement wise distribution of farmers by their attitude towards the extension system of State Department of Agriculture

\begin{tabular}{|c|c|c|c|c|c|c|c|}
\hline S No. & Statements & $\begin{array}{l}\text { SA } \\
\text { (1) }\end{array}$ & $\begin{array}{c}\text { A } \\
(2)\end{array}$ & $\begin{array}{l}\text { UD } \\
\text { (3) }\end{array}$ & $\begin{array}{l}\text { DA } \\
\text { (4) }\end{array}$ & $\begin{array}{c}\text { SDA } \\
(5)\end{array}$ & MWS \\
\hline 1. & $\begin{array}{l}\text { Crop production has substantially } \\
\text { increased due to the introduction of the } \\
\text { SDoA services in the area. }\end{array}$ & $\begin{array}{c}20 \\
(22.22)\end{array}$ & $\begin{array}{c}29 \\
(32.22)\end{array}$ & $\begin{array}{c}22 \\
(24.44)\end{array}$ & $\begin{array}{c}16 \\
(17.77)\end{array}$ & $\begin{array}{c}3 \\
(3.33)\end{array}$ & 3.52 \\
\hline 2. & $\begin{array}{l}\text { Regular contacts with the field } \\
\text { functionaries of the department motivated } \\
\text { farmers to adopt improved practices. }\end{array}$ & $\begin{array}{c}19 \\
(21.11)\end{array}$ & $\begin{array}{c}29 \\
(32.22)\end{array}$ & $\begin{array}{c}28 \\
(31.11)\end{array}$ & $\begin{array}{c}12 \\
(13.33)\end{array}$ & $\begin{array}{c}2 \\
(2.22)\end{array}$ & 3.56 \\
\hline 3. & $\begin{array}{l}\text { State Department of Agriculture } \\
\text { services/activities seem to be the same } \\
\text { from year to year. }\end{array}$ & $\begin{array}{c}35 \\
(38.88)\end{array}$ & $\begin{array}{c}22 \\
(24.44)\end{array}$ & $\begin{array}{c}15 \\
(16.66)\end{array}$ & $\begin{array}{c}10 \\
(11.11)\end{array}$ & $\begin{array}{c}8 \\
(8.88)\end{array}$ & 2.26 \\
\hline 4. & $\begin{array}{l}\text { The information that comes from the } \\
\text { SDoA is of practical use to farmers. }\end{array}$ & $\begin{array}{c}13 \\
(14.44)\end{array}$ & $\begin{array}{c}43 \\
(47.77)\end{array}$ & $\begin{array}{c}14 \\
(15.55)\end{array}$ & $\begin{array}{c}20 \\
(22.22)\end{array}$ & $\begin{array}{c}0 \\
(0.00)\end{array}$ & 3.54 \\
\hline 5. & $\begin{array}{l}\text { SDoA services helps in improving } \\
\text { farmer's income. }\end{array}$ & $\begin{array}{c}8 \\
(8.88)\end{array}$ & $\begin{array}{c}45 \\
(50.00)\end{array}$ & $\begin{array}{c}12 \\
(13.33)\end{array}$ & $\begin{array}{c}25 \\
(27.77)\end{array}$ & $\begin{array}{c}0 \\
(0.00)\end{array}$ & 3.40 \\
\hline 6. & $\begin{array}{l}\text { Activities selected under the State } \\
\text { Department of Agriculture are not } \\
\text { according to the needs of the farming } \\
\text { community. }\end{array}$ & $\begin{array}{c}4 \\
(4.44)\end{array}$ & $\begin{array}{c}25 \\
(27.77)\end{array}$ & $\begin{array}{c}26 \\
(28.88)\end{array}$ & $\begin{array}{c}33 \\
(36.66)\end{array}$ & $\begin{array}{c}2 \\
(2.22)\end{array}$ & 3.04 \\
\hline 7. & Only resourceful farmers can get the & 22 & 47 & 10 & 5 & 6 & 2.17 \\
\hline
\end{tabular}




\begin{tabular}{|c|c|c|c|c|c|c|c|}
\hline & benefit of SDoA. & (24.44) & $(52.22)$ & (11.11) & $(5.55)$ & $(6.66)$ & \\
\hline 8. & $\begin{array}{l}\text { The department has well qualified and } \\
\text { trained manpower. }\end{array}$ & $\begin{array}{c}25 \\
(27.77)\end{array}$ & $\begin{array}{c}42 \\
(46.66)\end{array}$ & $\begin{array}{c}12 \\
(13.33)\end{array}$ & $\begin{array}{c}7 \\
(7.77)\end{array}$ & $\begin{array}{c}4 \\
(4.44)\end{array}$ & 3.85 \\
\hline 9. & $\begin{array}{l}\text { Extension workers in SDoA had } \\
\text { maintained good rapport with the farmers. }\end{array}$ & $\begin{array}{c}11 \\
(12.22)\end{array}$ & $\begin{array}{c}32 \\
(35.55)\end{array}$ & $\begin{array}{c}23 \\
(25.55)\end{array}$ & $\begin{array}{c}21 \\
(23.33)\end{array}$ & $\begin{array}{c}3 \\
(3.33)\end{array}$ & 3.30 \\
\hline 10. & $\begin{array}{l}\text { There is difficulty in contacting field } \\
\text { functionaries of SDoA. }\end{array}$ & $\begin{array}{c}22 \\
(24.44)\end{array}$ & $\begin{array}{c}49 \\
(54.44)\end{array}$ & $\begin{array}{c}14 \\
(15.55)\end{array}$ & $\begin{array}{c}5 \\
(5.55)\end{array}$ & $\begin{array}{c}0 \\
(0.00)\end{array}$ & 2.02 \\
\hline 11. & $\begin{array}{l}\text { The farmers meetings are not regularly } \\
\text { conducted by the Agriculture supervisors. }\end{array}$ & $\begin{array}{c}39 \\
(43.33)\end{array}$ & $\begin{array}{c}26 \\
(28.88)\end{array}$ & $\begin{array}{c}13 \\
(14.44)\end{array}$ & $\begin{array}{c}3 \\
(3.33)\end{array}$ & $\begin{array}{c}9 \\
(10.00)\end{array}$ & 1.67 \\
\hline 12. & $\begin{array}{l}\text { State Department of Agriculture offers its } \\
\text { services through multiple extension } \\
\text { methods. }\end{array}$ & $\begin{array}{c}20 \\
(22.22)\end{array}$ & $\begin{array}{c}43 \\
(47.77)\end{array}$ & $\begin{array}{c}14 \\
(15.55)\end{array}$ & $\begin{array}{c}10 \\
(11.11)\end{array}$ & $\begin{array}{c}3 \\
(3.33)\end{array}$ & 3.74 \\
\hline 13. & $\begin{array}{l}\text { SDoA helps farmers to develop links with } \\
\text { other local cooperative and societies. }\end{array}$ & $\begin{array}{c}17 \\
(18.88)\end{array}$ & $\begin{array}{c}31 \\
(34.44)\end{array}$ & $\begin{array}{c}17 \\
(18.88)\end{array}$ & $\begin{array}{c}19 \\
(21.11)\end{array}$ & $\begin{array}{c}6 \\
(6.66)\end{array}$ & 3.37 \\
\hline 14. & $\begin{array}{l}\text { Service provided by SDOA is similar to } \\
\text { the activities of KVKs and the other line } \\
\text { departments. }\end{array}$ & $\begin{array}{c}32 \\
(35.55)\end{array}$ & $\begin{array}{c}22 \\
(24.44)\end{array}$ & $\begin{array}{c}12 \\
(13.33)\end{array}$ & $\begin{array}{c}15 \\
(16.66)\end{array}$ & $\begin{array}{c}9 \\
(10.00)\end{array}$ & 2.41 \\
\hline 15. & $\begin{array}{l}\text { FLD's conducted by SDoA encourages the } \\
\text { farmers to adopt newly released crop } \\
\text { production technology. }\end{array}$ & $\begin{array}{c}19 \\
(21.11)\end{array}$ & $\begin{array}{c}44 \\
(48.88)\end{array}$ & $\begin{array}{c}11 \\
(12.22)\end{array}$ & $\begin{array}{c}12 \\
(13.33)\end{array}$ & $\begin{array}{c}4 \\
(4.44)\end{array}$ & 3.68 \\
\hline 16. & $\begin{array}{l}\text { Existing infrastructure and facilities of } \\
\text { SDoA are not enough to meet the needs of } \\
\text { the farmers. }\end{array}$ & $\begin{array}{c}26 \\
(28.88)\end{array}$ & $\begin{array}{c}41 \\
(45.55)\end{array}$ & $\begin{array}{c}9 \\
(10.00)\end{array}$ & $\begin{array}{c}12 \\
(13.33)\end{array}$ & $\begin{array}{c}2 \\
(2.22)\end{array}$ & 2.14 \\
\hline 17. & $\begin{array}{l}\text { SDoA timely organize need based training } \\
\text { at every season. }\end{array}$ & $\begin{array}{c}20 \\
(22.22)\end{array}$ & $\begin{array}{c}39 \\
(43.33)\end{array}$ & $\begin{array}{c}16 \\
(17.77)\end{array}$ & $\begin{array}{c}12 \\
(13.33)\end{array}$ & $\begin{array}{c}3 \\
(3.33)\end{array}$ & 3.67 \\
\hline 18. & $\begin{array}{l}\text { There is no adequate follow-up of the } \\
\text { department programmes/activities. }\end{array}$ & $\begin{array}{c}12 \\
(13.33)\end{array}$ & $\begin{array}{c}47 \\
(52.22)\end{array}$ & $\begin{array}{c}9 \\
(10.00)\end{array}$ & $\begin{array}{c}22 \\
(24.44)\end{array}$ & $\begin{array}{c}0 \\
(0.00)\end{array}$ & 2.45 \\
\hline 19. & $\begin{array}{l}\text { The activities of the SDoA are confined } \\
\text { only to a few crops and don't cover the } \\
\text { allied fields such as animal husbandry, } \\
\text { poultry, dairy etc. }\end{array}$ & $\begin{array}{c}7 \\
(7.77)\end{array}$ & $\begin{array}{c}55 \\
(61.11)\end{array}$ & $\begin{array}{c}7 \\
(7.77)\end{array}$ & $\begin{array}{c}21 \\
(23.33)\end{array}$ & $\begin{array}{c}0 \\
(0.00)\end{array}$ & 2.46 \\
\hline 20. & $\begin{array}{l}\text { Extension functionaries of SDoA make } \\
\text { use of farmer's suggestion/ in subsequent } \\
\text { programmes/activities. }\end{array}$ & $\begin{array}{c}0 \\
(0.00)\end{array}$ & $\begin{array}{c}34 \\
(37.77)\end{array}$ & $\begin{array}{c}0 \\
(0.00)\end{array}$ & $\begin{array}{c}32 \\
(35.55)\end{array}$ & $\begin{array}{c}24 \\
(26.66)\end{array}$ & 2.48 \\
\hline 21. & $\begin{array}{l}\text { The SDoA services fail to develop self } \\
\text { reliance among the farmers and farm } \\
\text { women. }\end{array}$ & $\begin{array}{c}20 \\
(22.22)\end{array}$ & $\begin{array}{c}40 \\
(44.44)\end{array}$ & $\begin{array}{c}17 \\
(18.88)\end{array}$ & $\begin{array}{c}5 \\
(5.55)\end{array}$ & $\begin{array}{c}8 \\
(8.88)\end{array}$ & 2.34 \\
\hline 22. & $\begin{array}{l}\text { Kisan Seva Kendra helps to solve the } \\
\text { urgent problems of farmers regarding } \\
\text { input arrangements, insect and pest control } \\
\text { etc. }\end{array}$ & $\begin{array}{c}18 \\
(20.00)\end{array}$ & $\begin{array}{c}45 \\
(50.00)\end{array}$ & $\begin{array}{c}7 \\
(7.77)\end{array}$ & $\begin{array}{c}17 \\
(18.88)\end{array}$ & $\begin{array}{c}3 \\
(3.33)\end{array}$ & 3.64 \\
\hline 23. & $\begin{array}{l}\text { The information that the extension } \\
\text { personnel put out are common and already } \\
\text { known. }\end{array}$ & $\begin{array}{c}5 \\
(5.55)\end{array}$ & $\begin{array}{c}26 \\
(28.88)\end{array}$ & $\begin{array}{c}15 \\
(16.66)\end{array}$ & $\begin{array}{c}39 \\
(43.33)\end{array}$ & $\begin{array}{c}5 \\
(5.55)\end{array}$ & 3.14 \\
\hline 24. & $\begin{array}{l}\text { Phone-in-line (KCC) with scientists gives } \\
\text { first-hand information about queries. }\end{array}$ & $\begin{array}{c}6 \\
(6.66)\end{array}$ & $\begin{array}{c}20 \\
(22.22)\end{array}$ & $\begin{array}{c}10 \\
(11.11)\end{array}$ & $\begin{array}{c}21 \\
(23.33)\end{array}$ & $\begin{array}{c}33 \\
(36.66)\end{array}$ & 2.38 \\
\hline 25. & $\begin{array}{l}\text { Proper guidance is not provided by SDoA } \\
\text { personnel for initiating sound economic } \\
\text { activity or establishment of agro based } \\
\text { enterprise. }\end{array}$ & $\begin{array}{c}47 \\
(52.22)\end{array}$ & $\begin{array}{c}24 \\
(26.66)\end{array}$ & $\begin{array}{c}19 \\
(21.11)\end{array}$ & $\begin{array}{c}0 \\
(0.00)\end{array}$ & $\begin{array}{c}0 \\
(0.00)\end{array}$ & 1.68 \\
\hline
\end{tabular}


Table.2 Distribution of farmers by their attitude towards the services of State Department of Agriculture

\begin{tabular}{|l|l|c|c|}
\hline \multicolumn{1}{|c}{ S.No. } & \multicolumn{1}{c}{ Attitude categories } & f & \% \\
\hline 1. & Most Favorable (4.51-5.00) & 0 & 0.00 \\
\hline 2. & Favorable (3.51-4.50) & 29 & 32.22 \\
\hline 3. & Neutral (2.51-3.50) & 18 & 20.00 \\
\hline 4. & Unfavorable (1.51-2.50) & 43 & 47.78 \\
\hline 5. & Most Unfavorable (1.00-1.50) & 0 & 0.00 \\
\hline \multicolumn{4}{|c|}{ Mean Attitude Score $=2.84$} \\
\end{tabular}

Table.3 Significance of difference in attitude of farmers of different sub-districts

\begin{tabular}{|l|l|c|c|}
\hline S.No. & Sub-districts & Mean score & F value \\
\hline 1. & Badgaon $\left(\mathrm{n}_{1}=30\right)$ & 2.73 & $2.37627^{\mathrm{NS}}$ \\
\cline { 1 - 1 } 2. & Girwa $\left(\mathrm{n}_{2}=30\right)$ & 2.66 & \\
\cline { 1 - 2 } & Salumber $\left(\mathrm{n}_{3}=30\right)$ & 2.61 & \\
\hline
\end{tabular}

The overall attitude of the farmers towards the agricultural extension system of the State Department of Agriculture

The data presented in Table 2 reveal that nearly half of the respondents $(47.78 \%)$ were having an unfavourable attitude towards the transfer of technology system of Department of Agriculture whereas, 32.22 per cent of the respondents were favourably disposed to the extension services of the State Department of Agriculture. There were only 20.00 per cent of respondents who had a neutral attitude towards the services of the department. None of the respondents showed the most favourable and most unfavourable attitude towards the extension system. The mean attitude score of the findings (2.84 MAS) reflects that most of the respondents were unsatisfied with the extension services of the department available in their area. This was due to the poor performance of the department in timely delivering better and desired services to the farmers. Majority of the farmers felt that it was not easy to get benefit from the department when needed due to lesser targets and complicated procedure. The farmers also perceived the inputs provided by the department as costly and of degraded quality. The findings are in line with the Sa'adatu et al. (2011) who analyzed the perception of farmers towards Commercialization and Privatization (C and $\mathrm{P})$ of agricultural extension service programme and revealed that the farmer's perception level was very low even though their awareness level was very high. Similar findings were also reported by Qtaishat and Sharafat (2012).The results of the study revealed that the farmers' overall attitude towards the public agricultural extension activities was negative, they were not satisfied with the services.

Perusal of data in Table 3 indicates mean scores of attitude of farmers in all the three sub-districts of Udaipur. F value indicate that no significant difference was found in the 
mean attitude scores of farmers in different sub- districts. This may be due to the reason that there was uniformity of schemes, services and information provided to the farmers by the state department of agricultural in Udaipur.

In conclusion, the effectiveness of the department programmes mainly depends upon the involvement and participation of farmers in the activities conducted by the department, which in turn is reflected by their attitude. From the findings, it can be inferred that the majority of the respondents had unfavourable attitude towards the extension system of the State Department of Agriculture as depicted by the overall mean attitude score 2.8 . This was mainly due to lack of need-based programme, unavailability of concerned functionaries as and when needed, irregular meetings, inadequate infrastructure facilities, lack of entrepreneurial activities and inadequate follow-up of activities. Hence, it is suggested to the department authority or programme planners to pay special attention to the farmer's feedback and complaints so as to make the services better and effective.

\section{References}

Jaisridhar, P., Sankhala, G., Kumar, R. S. and
Sangeetha, S. 2013. Attitude of the dairy farmers towards Kisan Call Centre (KCC) Agro-Advisory Services. Article published by Agricultural Research Communication Centre. Retrieved from https://www.facebook.com/permalink.p hp?id=151237751571920\&story fbid $=634453296583694$. Dated18/02/2020.

Qtaishat, T. and Sharafat, A. 2012. Attitudes of Vegetable Farmers Towards Public Agricultural Extension Services. American Journal of Agricultural and Biological Sciences. 7: 370-377. Retrieved from http://www.thescipub.com/ajabs.toc.

Dated 10/02/2020.

Sa'adatu, B.A., Usman, S. and Dahiru, B. 2011. Maize Farmers' Perception of Commercialization and Privatization of Agricultural Extension Services in North Senatorial District of Gombe State, Nigeria. Journal of Agricultural Extension. 15: 75-83.

Tawari, C.C. and Davies, O.A. 2010. The attitude of fisher folks towards agricultural extension services in niger delta, Nigeria. International Journal of Pharma and Bio Sciences.1:1-15.

\section{How to cite this article:}

Manisha Pandey, Dhriti Solanki and Shalini Pandey. 2020. Attitude of Farmers towards the Agricultural Extension System of State Department of Agriculture. Int.J.Curr.Microbiol.App.Sci. 9(04): 352-358. doi: https://doi.org/10.20546/ijcmas.2020.904.041 